\title{
Intravenous Thrombolysis for Embolic Stroke due to Cardiac Myxoma
}

\author{
Mu-Chien Sun ${ }^{a}$ Hui-Chun Tai ${ }^{b}$ Chien-Hui Lee ${ }^{c}$ \\ Departments of a Neurology, bPathology and ${ }^{\mathrm{c} C a r d i o v a s c u l a r ~ S u r g e r y, ~ C h a n g h u a ~}$ \\ Christian Hospital, Changhua, Taiwan, ROC
}

\section{Key Words}

Stroke - Atrial myxoma - Thrombolysis · Recombinant tissue plasminogen activator

\begin{abstract}
Cardiac myxoma is a rare but curable cause of ischemic stroke. Current guidelines do not address the use of intravenous thrombolysis for embolic stroke caused by cardiac myxoma. The risk of hemorrhage due to occult tumor emboli or microaneurysms is a major concern. We describe a 45-year-old man who had an embolic stroke in the left middle cerebral artery. The initial National Institutes of Health Stroke Scale (NIHSS) score was 16 . He received intravenous thrombolysis $2 \mathrm{~h}$ and $52 \mathrm{~min}$ after stroke onset. No intracranial hemorrhage developed. A cardiac mass was found in the left atrium and removed surgically $84 \mathrm{~h}$ after stroke. Pathological study showed a myxoma with extensive hemorrhage and thrombus over the surface. At the 3-month follow-up, the NIHSS score was 9 and the modified Rankin scale score was 3. Our experience with this patient supports the hypothesis that intravenous thrombolysis may be safely used in the treatment of embolic stroke due to cardiac myxoma.
\end{abstract}

\section{Introduction}

Left atrial myxoma is a rare but curable cause of ischemic stroke. Embolic stroke and transient ischemic attack are among the common manifestations [1-3]. In a hospitalbased series, stroke occurred in $20.3 \%$ (23/112) of patients with left atrial cardiac myxoma [1]. In a review of neurological manifestations of cardiac myxoma, hemorrhagic stroke could be found in $16.8 \%(19 / 113)$ and ischemic stroke in $82.3 \%(93 / 113)$ of all cases [3], and stroke caused significant disability in most patients. Intravenous thrombolysis is an important treatment for ischemic stroke. However, experience in using intravenous thrombolysis for the treatment of embolic stroke due to left atrial myxoma is limited. 


\section{Case Report}

A 45-year-old male without known cardiovascular risk factors had a sudden onset of right limb weakness and difficulty in verbal expression. Upon arrival at the emergency department, his blood pressure was $118 / 74 \mathrm{~mm} \mathrm{Hg}$, the heart rate was $82 \mathrm{bpm}$ and regular, and the body temperature was $37.0^{\circ} \mathrm{C}$. An electrocardiogram showed sinus rhythm and incomplete right branch bundle block. On $\mathrm{X}$-ray, an enlargement of the cardiac silhouette was noted. The National Institutes of Health Stroke Scale (NIHSS) score was 16 and the head CT scan was normal. All criteria for intravenous thrombolysis were met, thus the patient received $0.9 \mathrm{mg} / \mathrm{kg}$ i.v. recombinant tissue plasminogen activator ( $\mathrm{rtPA}$, a total of $54 \mathrm{mg}$ ) per standard protocol $47 \mathrm{~min}$ after arrival at the emergency department and $2 \mathrm{~h}$ and 52 min after symptom onset. A follow-up CT scan revealed hypodense lesions in the left basal ganglia and corona radiata without evidence of hemorrhage (fig. 1a). There was no change in the NIHSS score $24 \mathrm{~h}$ after treatment. An urgent transthoracic echocardiogram was carried out because of the enlargement of the cardiac silhouette seen on the chest X-ray. A large mass with irregular shape within the left atrium was found. This finding was confirmed with a CT scan of the chest and the heart (fig. 1b). Urgent cardiac surgery was performed $84 \mathrm{~h}$ after presentation. A large, reddish, elastic mass, $8.0 \times 4.7 \times 3.7 \mathrm{~cm}$ in size, was removed from the left atrium. The cut surface of the atrial tumor revealed a gelatinous texture with a congested and irregular surface. There was also a cystic degeneration in the central portion (fig. 2a). Microscopically, the irregular surface of the atrial tumor was hemorrhagic and focally coated with blood clots composed of blood cells admixed with fibrinous material. In a high-power field, polygonal and spindle-shaped tumor cells were arranged in a single cord or in nests within the myxoid stroma with some capillary-sized vessels (fig. 2b). The tumor cells were calretinin positive and CD31 negative, which differentiate them from endothelial cells of the granulation tissue or endocardial cells (fig. 2c). The findings were diagnostic of cardiac myxoma. The patient was discharged to receive rehabilitation. At the 3-month follow-up, the NIHSS score was 9 and the modified Rankin scale score was 3.

\section{Discussion}

Cardiac myxoma is the most common primary tumor of the heart and more prevalent in women than in men [1]. Age at diagnosis is usually less than 60 years. In a study by Alvarez-Sabín et al. [2], patients with neurological events were younger at diagnosis than those without neurological manifestations (mean 49 vs. 61 years). The most common initial symptoms of left atrial myxoma include cardiac manifestations such as heart failure, syncope, or arrhythmias, systemic manifestations such as fever, weight loss, or fatigue, and embolic events such as cerebral embolism, peripheral embolism, or coronary embolism. Embolic stroke is the most common neurological manifestation [1-3].

To our knowledge, the use of intravenous thrombolytic therapy in embolic stroke caused by cardiac myxoma has only been reported in 4 cases [4-7]. The first reported case presented with cerebellar hemorrhage and parietal subarachnoid hemorrhage $5 \mathrm{~h}$ after treatment [4]. The tumor was $3 \times 4 \mathrm{~cm}$ in size, very friable, and gelatinous and fragmented easily with minimal manipulation. The hemorrhages were suspected to be secondary to tumor emboli or microaneurysms. Sabolek et al. [8] found cerebral aneurysms in patients with cardiac myxoma, with a median number of 3.0 aneurysms per patient. Thus, the safety of intravenous thrombolysis in these patients was a concern. The greater risk of hemorrhage due to occult tumor emboli or microaneurysms should therefore be considered.

Three later reported cases of intravenous thrombolysis for ischemic stroke caused by cardiac myxoma were all successful [5-7], and no hemorrhage occurred. The three cases were younger and had shorter onset-to-treatment times than the first reported case (table 1). The tumor in one case was $6.4 \times 5.0 \times 4.0 \mathrm{~cm}$ in size and encapsulated [6]. Although 
morphology of the other case was not addressed, thrombus rather than tumor embolus was presumed to be the cause of the stroke [5]. Emboli due to cardiac myxomas are often tumor fragments but may also arise from a thrombus that is formed on the surface of the myxoma [9]. Tumor emboli are presumably less responsive to thrombolytic therapy [46]. Pathological results in our case demonstrated extensive hemorrhage and inflammatory infiltrate of the tumor as well as a thrombus over the surface. In our patient, emboli could be a pure thrombus or thrombotic propagation of tumor material.

Intra-arterial thrombolysis following diagnostic angiography is thought to minimize the risk of hemorrhage in patients with cardiac myxoma by excluding a pseudoaneurysm and minimizing fibrinolytic exposure to unaffected vessels [10]. To our knowledge, there are two reported cases of intra-arterial thrombolysis for stroke due to cardiac myxoma in the literature $[10,11]$. A 57-year-old woman with right middle cerebral artery occlusion was treated with $1 \mathrm{MU}$ urokinase $3.5 \mathrm{~h}$ following the onset of symptoms. Although there was no intracranial hemorrhage, the patient died. Significant brain swelling with subfalcine herniation and subsequent transtentorial herniation was found [10]. The other case was a 62-year-old woman with right middle cerebral artery occlusion. She was treated with rtPA within $3 \mathrm{~h}$ after stroke. Partial re-canalization was obtained without hemorrhage. She returned to work 9 months after receiving treatment [11].

In a study by Ekinci and Donnan [3], hemorrhagic stroke (intracerebral hemorrhage and subarachnoid hemorrhage) could be found in $16.8 \%$ (19/113) of neurological manifestations of cardiac myxoma. For our case and other reported cases with intravenous rtPA thrombolysis, the rate of intracranial hemorrhage was $20 \%(1 / 5)$. If cases with intra-arterial thrombolysis are included, the rate was $16.7 \%(1 / 6)$ for rtPA thrombolysis and $14.3 \%$ (1/7) for all thrombolysis cases. In the Safe Implementation of Thrombolysis in Stroke-Monitoring Study [12], the rate of intracerebral hemorrhages detected by CT or MRI was $14.5 \%(869 / 6,283) 22-36 \mathrm{~h}$ after intravenous rtPA thrombolysis and $17.1 \%(1,085 / 6,352)$ in any post-treatment imaging scans. Intravenous thrombolytic therapy for acute stroke requires a timely process to shorten the time to treatment [13]. Current guidelines do not deal with cardiac myxoma. In addition, the diagnosis of cardiac myxomatous embolism is rarely made before treatment. Although the number of reported cases is small, intravenous thrombolytic therapy for stroke caused by cardiac myxoma might not be as risky as previously thought. 


\begin{tabular}{l|l|l|l}
$\begin{array}{c}\text { Case Reports in } \\
\text { NeUlology }\end{array}$ & $\begin{array}{l}\text { Case Rep Neurol 2011;3:21-26 } \\
\text { DOI: 10.1159/000324095 }\end{array}$ & $\begin{array}{l}\text { Published online: } \\
\text { January 20, 2011 }\end{array}$ & $\begin{array}{l}\text { O 2011 S. Karger AG, Basel } \\
\text { ISSN 1662-680X } \\
\text { www.karger.com/crn }\end{array}$ \\
\hline
\end{tabular}

Table 1. Clinical manifestation of patients with intravenous thrombolysis for embolic stroke due to cardiac myxoma

\begin{tabular}{llllll}
\hline Reference & $\begin{array}{l}\text { Age/ } \\
\text { sex }\end{array}$ & $\begin{array}{l}\text { OTT } \\
\text { min }\end{array}$ & $\begin{array}{l}\text { NIHSS } \\
\text { score }\end{array}$ & $\begin{array}{l}\text { Intracranial } \\
\text { hemorrhage }\end{array}$ & Outcome \\
\hline Chong et al. [4] & $74 / \mathrm{F}$ & 180 & 6 & yes & aphasia \\
Ibrahim et al. [5] & $51 / \mathrm{M}$ & 84 & 22 & no & complete recovery \\
Nagy et al. [6] & $26 / \mathrm{M}$ & 105 & 10 & no & minimal hand weakness at 2 years \\
Ong and Chang [7] & 22/F & 125 & 12 & no & NIHSS score 5 at 10 months \\
This report & $45 / \mathrm{M}$ & 172 & 16 & no & motor aphasia and right hemiparesis at 3 months \\
\hline
\end{tabular}

OTT $=$ Onset-to-treatment time.
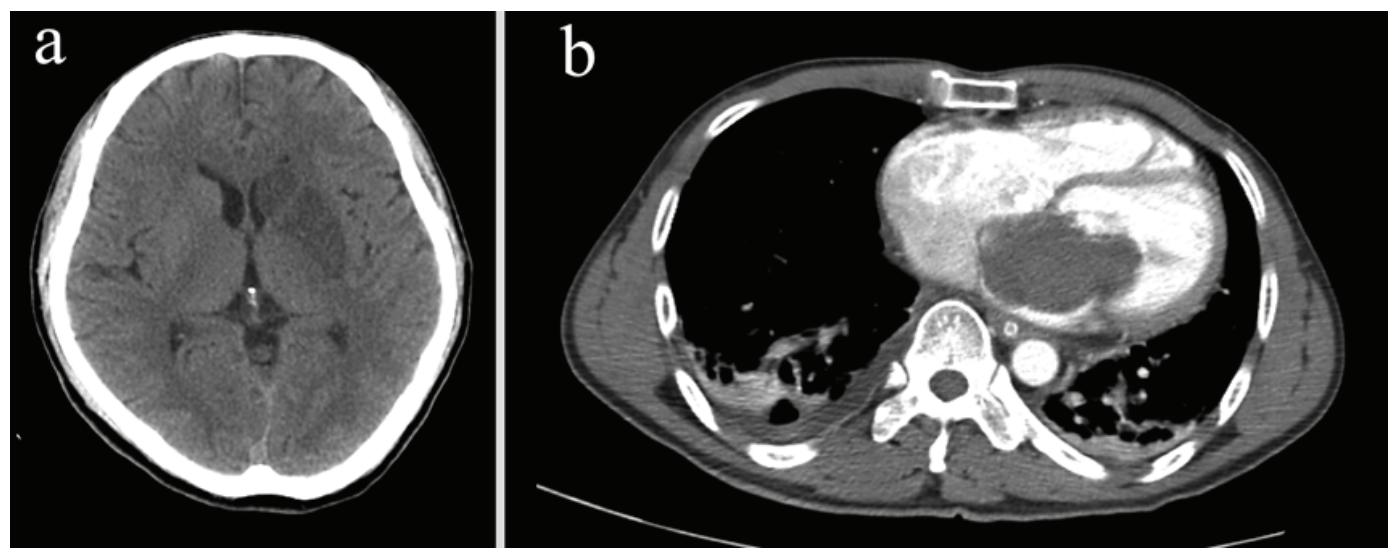

Fig. 1. Head CT scan $27 \mathrm{~h}$ after thrombolysis shows hypodense lesions in the left basal ganglia and corona radiata without evidence of hemorrhage (a). CT scan of the chest and the heart with contrast shows a large filling defect in the left atrium (b). 


\begin{tabular}{c|l|l|l}
$\begin{array}{c}\text { Case Reports in } \\
\text { NeUlology }\end{array}$ & $\begin{array}{l}\text { Case Rep Neurol 2011;3:21-26 } \\
\text { DOI: 10.1159/000324095 }\end{array}$ & $\begin{array}{l}\text { Published online: } \\
\text { January 20, 2011 }\end{array}$ & $\begin{array}{l}\text { O 2011 S. Karger AG, Basel } \\
\text { ISSN 1662-680X } \\
\text { www.karger.com/crn }\end{array}$ \\
\hline
\end{tabular}
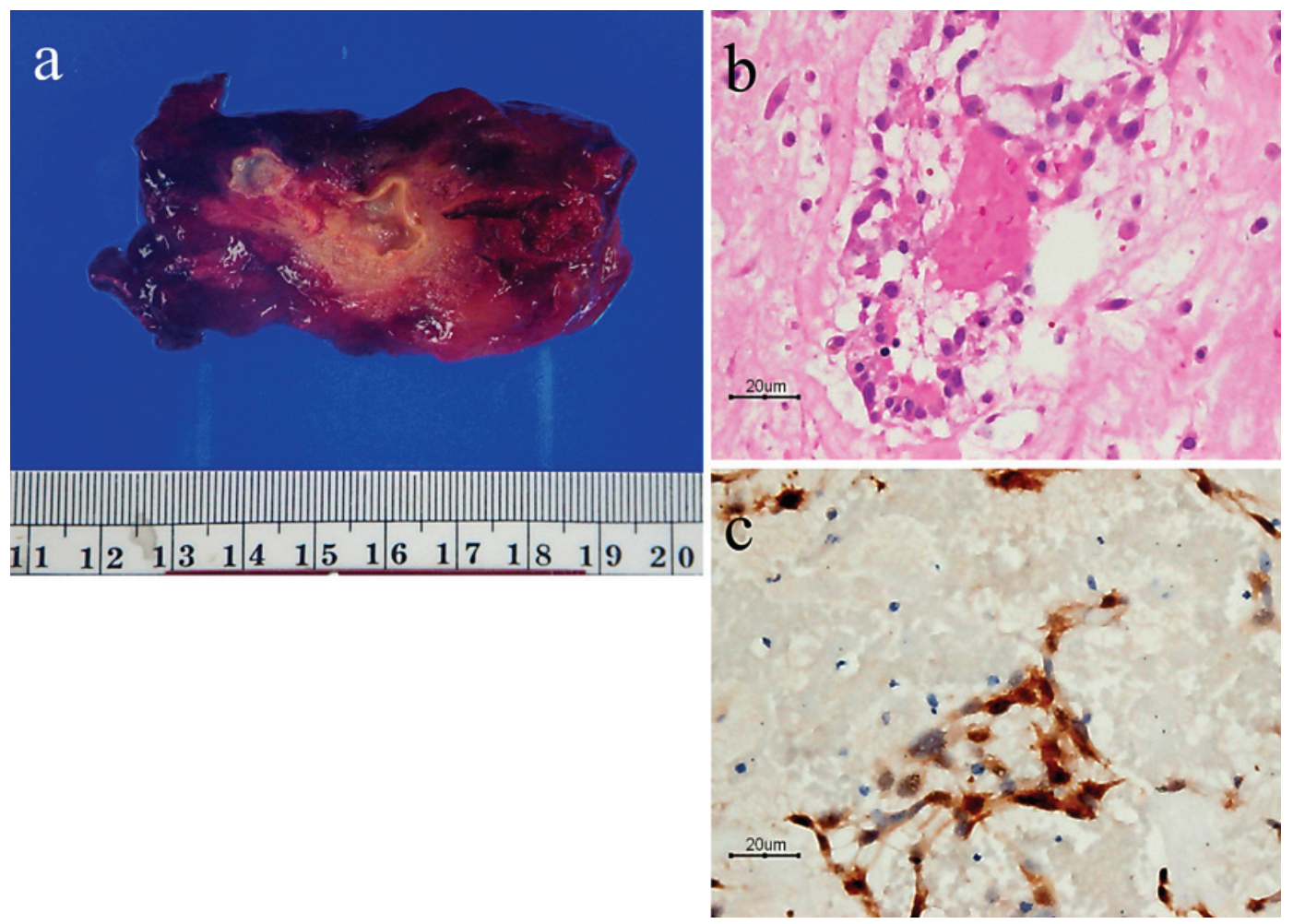

Fig. 2. A photomicrograph of the $8.0 \times 4.7 \times 3.7 \mathrm{~cm}$ cardiac tumor removed at the operation (a). Microscopically, polygonal and spindle cells were arranged in a single cord or in nests and embedded in the myxoid stroma (HE) (b). The tumor cells show immunoreactivity to calretinin (immunohistochemical stain, anti-calretinin) (c).

\section{References}

1 Pinede L, Duhaut P, Loire R: Clinical presentation of left atrial cardiac myxoma. A series of 112 consecutive cases. Medicine 2001;80:159-172.

-2 Alvarez-Sabín J, Lozano M, Sastre-Garriga J, Montoyo J, Murtra M, Abilleira S, Codina A: Transient ischaemic attack: a common initial manifestation of cardiac myxomas. Eur Neurol 2001;45:165-170.

3 Ekinci EI, Donnan GA: Neurological manifestations of cardiac myxoma: a review of the literature and report of cases. Intern Med J 2004;34:243-249.

4 Chong JY, Vraniak P, Etienne M, Sherman D, Elkind MSV: Intravenous thrombolytic treatment of acute ischemic stroke associated with left atrial myxoma: a case report. J Stroke Cerebrovasc Dis 2005;14:39-41.

-5 Ibrahim M, Iliescu C, Safi HJ, Buja ML, McPherson DD, Fuentes F: Biatrial myxoma and cerebral ischemia successfully treated with intravenous thrombolytic therapy and surgical resection. Tex Heart Inst J 2008;35:193-195.

-6 Nagy CD, Levy M, Mulhearn TJ, Shapland M, Sun H, Yuh DD, Cheung D, Chandra-Strobos N: Safe and effective intravenous thrombolysis for acute ischemic stroke caused by left atrial myxoma. J Stroke Cerebrovasc Dis 2009;18:398-402.

7 Ong CT, Chang RY: Intravenous thrombolysis of occlusion in the middle cerebral and retinal arteries from presumed ventricular myxoma. Stroke Res Treat DOI: 10.4061/2011/735057.

8 Sabolek M, Bachus-Banaschak K, Bachus R, Arnold G, Storch A: Multiple cerebral aneurysms as delayed complication of left cardiac myxoma: a case report and review. Acta Neurol Scand 2005;111:345-350.

9 Wold LE, Lie JT: Cardiac myxomas: a clinicopathologic profile. Am J Pathol 1980;101:219-240.

10 Bekavac I, Hanna JP, Wallace RC, Powers J, Ratliff NB, Furlan AJ: Intra-arterial thrombolysis of embolic proximal middle cerebral artery occlusion from presumed atrial myxoma. Neurology 1997;49:618-620. 
11 Yamanome T, Yoshida K, Miura K, Ogawa A: Superselective fibrinolysis for a middle cerebral artery embolism caused by a left atrial myxoma: case report. No Shinkei Geka 2000;28:653-658.

12 Wahlgren N, Ahmed N, Davalos A, Ford GA, Grond M, Hacke W, Hennerici MG, Kaste M, Kuelkens S, Larrue V, Lees KR, O Roine R, Soinne L, Toni D, Vanhooren G, SITS-MOST investigators: Thrombolysis with alteplase for acute ischaemic stroke in the Safe Implementation of Thrombolysis in Stroke-Monitoring Study (SITS-MOST): an observational study. Lancet 2007;369:275-282.

13 Adams HP, del Zoppo G, Alberts MJ, Bhatt DL, Brass L, Furlan A, Grubb RL, Higashida RT, Jauch EC, Kidwell C, Lyden PD, Morgenstern LB, Qureshi AI, Rosenwasser RH, Scott PA, Wijdicks EFM: Guidelines for the early management of adults with ischemic stroke: a guideline from the American Heart Association/American Stroke Association Stroke Council, Clinical Cardiology Council, Cardiovascular Radiology and Intervention Council, and the Atherosclerotic Peripheral Vascular Disease and Quality of Care Outcomes in Research Interdisciplinary Working Groups. Stroke 2007;38:1655-1711. 